\title{
"It's a stomachache filled with stress": Tracing the Uneven Spillover Effects of Racialized Police Violence Using Twitter Data
}

\author{
Hajar Yazdiha* is an assistant professor of sociology at \\ the University of Southern California.
}

Courtney Boen ${ }^{\dagger}$ is an assistant professor of sociology at the University of Pennsylvania.

Yazdiha, H., \& Boen, C. (2021). "It's a stomachache filled with stress": Tracing the uneven spillover effects of racialized police violence using Twitter data. Currents, (2)1.

Keywords: law and society, social movements, racialized stress, police violence

The killing of Michael Brown awakens a fear in me that touches to the core of my being - to the core of my motherhood: the fear that someone will harm or, worse, kill my child. I remember I sobbed for Sybrina Fulton [Trayvon Martin's mother] because I felt so connected to her pain. I can't explain why because I haven't endured that type of pain, but Sybrina was the mother whose pain and strength shook my core and changed me. . . I I identify with the mother's pain in a way that makes me ache. It's an actual stomachache. The kind that makes your appetite go away, makes you clutch your middle and for sure makes you grumpy ... It's a stomachache that no medication can take away

*hyazdiha@usc.edu

†cboen@upenn.edu 
because its symptoms are based on a problematic past and a not-sopromising future. It's a stomachache filled with the stress I feel over the racial divide in America and the scarce signs of progress I see for the future.

-Mo Ivory (2014)

Media, activists, and scholarly work have brought much needed attention to the devastating consequences of police violence and the uneven mortality risks from homicide by police. Black men face particularly high risks of police violence (Edwards, Esposito, \& Hedwig, 2018; Edwards, Lee, \& Esposito, 2019), with one in 1,000 Black men being killed by police over their life span (Edwards, Esposito, \& Hedwig, 2018). Still, the trauma associated with police violence is not limited to those who experience it firsthand. With the rise of portable video recorders and social media, police violence that was only observed in situ is recorded and broadcast to a global audience, made viral, and viewed repeatedly, broadening the reach of these spillover effects. The video of George Floyd's death under a white police officer's knee, for example, has been viewed over 1.4 billion times. In addition to the direct consequences of this violence for victims, studies also document a host of collateral and spill-over effects of the carceral system and police violence, ranging from decreased trust in the police and increased legal cynicism (Kirk and Matsuda 2011; Sampson and Bartusch 1998), to decreased citizen crime reporting (Desmond, Papachristos, and Kirk 2016), to increased mental health risk (Bor et al. 2018; DeVylder et al. 2018; DeVylder, Fedina, and Link 2020; McLeod et al. 2020; Sewell, Jefferson, and Lee 2016). Given racial disparities in the risk of police violence and the sociohistorical context of racism in the United States, the collateral consequences of this violence are especially magnified for Black communities relative to other groups.

Despite increased attention to the spillover effects of racialized police violence, questions about how to capture the collateral consequences of police violence for population health and well-being remain unanswered. How can we identify and trace the embodied trauma that "touches the core of a being," the "stomachache filled 
with stress," that Mo Ivory describes so hauntingly after Michael Brown's killing? How can we measure the immediate and longer-lasting effects of hearing about the horrors of police violence-feelings that are experienced so differently by Black and white Americans? These are the questions we contend with in this research project.

New forms of social connectivity like Twitter offer individuals platforms for expressing their emotions continuously in real time, offering researchers valuable insight into the effects of widely publicized events (Barbera, 2016; Golder \& Macy, 2011; Larsen et al., 2015; McCormick et al., 2017; Murthy, Gross, \& Pensavalle, 2016). Central to our research is the idea that measuring emotional outcomes offers a window into individual psyche and well-being and the production of health disparities in ways that are often overlooked by population health scientists. Emotions are fundamental to social life-windows into the patterned connections between structures and individuals (Ekman, 1992; Elster, 1999; Hochschild, 2002; Hoggett \& Thompson, 2012; Lewis, Haviland-Jones, \& Barrett, 2008; Manstead, Frijda, \& Fischer, 2004; Thoits, 1989; Turner \& Stets, 2005). Structures of power enable and constrain both the emotional stimuli that individuals are exposed to as well as the cultural tools available to them to process, make sense of, and react to these experiences (Bonilla-Silva, 2019; Hochschild, 1979; Hochschild, 2012; Wingfield, 2010). Studies show negative emotions like anger and anxiety increase stress responses in ways that harm health (Freund, 1990; Johnson \& Broman, 1987; Ross, 1993; Uskul \& Horn, 2015) while positive emotions can improve health (Cohen \& Pressman, 2006; Barbara Fredrickson \& Levenson, 1998; Stellar et al., 2015; Tugade, Fredrickson, \& Barrett, 2004). Still, these bodies of research have not been fully integrated to assess whether and how systems of social inequality-particularly racism-pattern exposure and vulnerability to emotional stimuli like police violence in ways that might matter for population well-being.

Our study uses longitudinal data, a quasinatural experiment design, and two nationally publicized cases - the killings of Michael Brown and Tamir Rice-to trace how police violence affects the emotional and 
psychological well-being of individuals. Analyzing a corpus of text data from over 200,000 unique Twitter users using computational text analysis, we evaluate the emotional and psychological spillover effects of police violence, paying particular attention to race, gender, age, and geographic disparities. In preliminary analyses, we found that the emotionality of users' tweets became more negative in the wake of both shootings, a finding that was particularly pronounced for Black Twitter users. In Figure 1 below, we display the changes in particularly salient negative emotions following the Michael Brown killing. In each of the graphs, the blue dots indicate the average scores for each sentiment before the shooting, and the black dots indicate the average scores after the shooting; the bars indicate $95 \%$ confidence intervals.

Findings from this study will generate new evidence of the racialized spillover effects of police violence, particularly the mechanisms that shape individual emotions, feelings of stress, and psychological well-being in ways that relate to individual health and contribute to population disparities. We also hope to add to the emergent work in computational social science that sees social media as a reflection of social processes, a space where real-world events are processed and internalized.
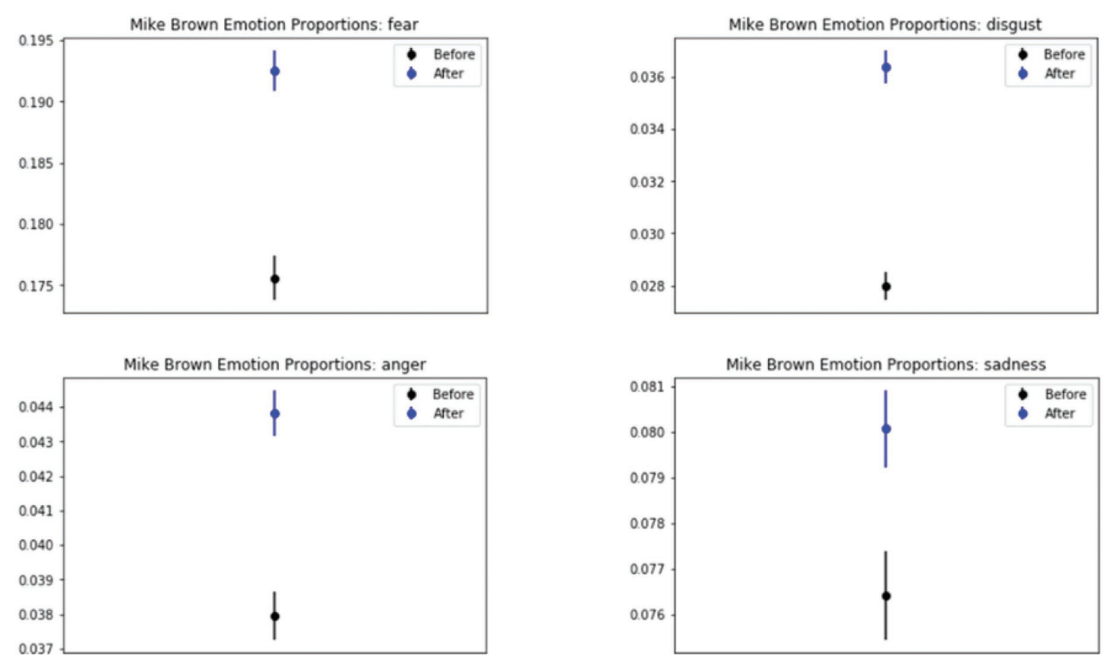

Figure 1 


\section{Biographies}

Dr. Hajar Yazdiha's research examines the mechanisms underlying the politics of inclusion and exclusion as they shape intergroup boundaries, ethnoracial identities, and intergroup relations.

Dr. Courtney Boen's work aims to improve understanding of the links between macro-level systems of inequality, meso-level institutional policies and environments, and micro-level biological and psychological processes in the production of population health disparities.

\section{References}

Adia Harvey Wingfield, A. H. (2010, May 1.) Are some emotions marked whites only? Racialized feeling rules in professional workplaces. Social Problems, 57(2), 251-268. https://doi.org/10.1525/sp.2010.57.2.251

Barbera, P. (2016). Less is more-How demographic sample weights can improve public opinion estimates based on twitter data. Retrieved from https://www.scribd.com/document/372046231/Less-is-More-HowDemographic-Sample-Weights-Can-Improve-Public-Opinion-EstimatesBased-on-Twitter-Data

Bor, Jacob, Atheendar S. Venkataramani, David R. Williams, and Alexander C. Tsai. 2018. "Police Killings and Their Spillover Effects on the Mental Health of Black Americans: A Population-Based, Quasi-Experimental Study." The Lancet 392(10144):302-10. doi: 10.1016/S0140-6736(18)31130-9

Catherine E. Ross, C. E. (1993, June 1.) Fear of victimization and health. Journal of Quantitative Criminology, 9(2), 159-175. https://doi.org/10.1007/ BF01071166

Cohen, S., \& Pressman, S. D. (2006, June 1). Positive affect and health. Current Directions in Psychological Science, 15(3), 122-25. https://doi.org/10.1111/ j.0963-7214.2006.00420.x

Desmond, M., Papachristos, A. V., \& Kirk, D. S. (2016, October 1). Police violence and citizen crime reporting in the black community. American Sociological Review, 81(5), 857-876. https://doi.org/10.1177/0003122416663494

DeVylder, Jordan E., Hyun-Jin Jun, Lisa Fedina, Daniel Coleman, Deidre Anglin, Courtney Cogburn, Bruce Link, and Richard P. Barth. 2018. "Association of Exposure to Police Violence With Prevalence of Mental Health Symptoms Among Urban Residents in the United States." JAMA Network Open 1(7):e184945-e184945. doi: 10.1001/jamanetworkopen.2018.4945 
DeVylder, Jordan, Lisa Fedina, and Bruce Link. 2020. "Impact of Police Violence on Mental Health: A Theoretical Framework." American Journal of Public Health 110(11):1704-10. doi: 10.2105/AJPH.2020.305874

Eduardo Bonilla-Silva, E. (2019, February 1.) Feeling race: Theorizing the racial economy of emotions. American Sociological Review, 84(1), 1-25. https:// doi.org/10.1177/0003122418816958

Edwards, F., Esposito, M. H., and Lee, H. (2018, September). Risk of policeinvolved death by race/ethnicity and place, United States, 2012-2018. American Journal of Public Health, 108(9), 1241-1248. https://doi. org/10.2105/AJPH.2018.304559

Edwards, F., Lee, H., \& Esposito, M. Risk of being killed by police use of force in the United States by age, race-ethnicity, and sex. Proceedings of the National Academy of Sciences, 116(34), 16793-16798. https://doi. org/10.1073/pnas.1821204116

Ekman, P. (1992). Are there basic emotions? Psychological Review, 99(3), 550-553. https://doi.org/10.1037/0033-295X.99.3.550

Elster, J. (1999). Alchemies of the mind: Rationality and the emotions. Cambridge University Press.

Fredrickson, B. L., \& Levenson, R. W. (1998, March 1.) Positive emotions speed recovery from the cardiovascular sequelae of negative emotions. Cognition and Emotion, 12(2), 191-220. https://doi.org/10.1080/026999398379718

Freund, P. E. S. (1990). The expressive body: A common ground for the sociology of emotions and health and illness. Sociology of Health \& IIIness 12(4), 452-77. https://doi.org/10.1111/1467-9566.ep11340419

Golder, S. A., \& Macy, M. W., Diurnal and seasonal mood vary with work, sleep, and daylength across diverse cultures. Science, 333(6051), 18781881. https://doi.org/10.1126/science.1202775

Hochschild, A. R. (1979, November 1.) Emotion work, feeling rules, and social structure. American Journal of Sociology, 85(3), 551-75. https://doi. org/10.2307/2778583

Hochschild, A. R. (2002, September 11.) The sociology of emotion as a way of seeing. Emotions in Social Life, 1. https://doi.org/10.4324/9780203437452-10

Hochschild, A. R. (2012). The managed heart commercialization of human feeling. University of California Press. http://site.ebrary.com/id/10555078

Hoggett, P. \& Thompson, S. (2012). Politics and the emotions: The affective turn in contemporary political studies. Continuum.

Johnson, E. H., \& Broman, C. L. (1987, April 1.) The relationship of anger expression to health problems among black Americans in a national survey. Journal of Behavioral Medicine 10(2), 103-16. https://doi.org/10.1007/ BF00846419

Kirk, D. S., \& Matsuda, M. (2011, May 1). Legal cynicism, collective efficacy, and the ecology of arrest. Criminology, 49(2), 443-472. https://doi. org/10.1111/j.1745-9125.2011.00226.x 
Larsen, M. E., Boonstra, T. W., Batterham, P. J., O'Dea, B., Paris, C., \& Christensen, H. (2015). We feel: Mapping emotion on twitter. IEEE Journal of Biomedical and Health Informatics, 19(4), 1246-52. https://doi.org/ 10.1109/JBHI.2015.2403839

Lewis, M., Haviland-Jones, J. M., \& Barrett, L. F. (2008). Handbook of emotions (3rd Ed.). Guilford Press.

Manstead, A S. R., Frijda, N., \& Fischer, A. (2004). Feelings and emotions: The Amsterdam symposium. Cambridge University Press.

McLeod, Melissa N., Daliah Heller, Meredith G. Manze, and Sandra E. Echeverria. 2020. "Police Interactions and the Mental Health of Black Americans: A Systematic Review." Journal of Racial and Ethnic Health Disparities 7(1):10-27. doi: 10.1007/s40615-019-00629-1

McCormick, T. H., Lee, H., Cesare, N., Shojaie, A., Spiro, E. S. Using Twitter for demographic and social science research: Tools for data collection and processing. Sociological Methods \& Research, 46(3), 390-421. https://doi. org/10.1177/0049124115605339

Murthy, D., Gross, A., and Pensavalle, A. Urban social media demographics: An exploration of Twitter use in major American cities. Journal of ComputerMediated Communication, 21(1), 33-49. https://doi.org/10.1111/jcc4.12144

Sampson, R. J., \& Bartusch, D. J. (1998). Legal cynicism and (subcultural?) tolerance of deviance: The neighborhood context of racial differences. Law \& Society Review, 32(4), 777-804. https://doi.org/10.2307/827739

Sewell, Abigail A., Kevin A. Jefferson, and Hedwig Lee. 2016. "Living under Surveillance: Gender, Psychological Distress, and Stop-Question-and-Frisk Policing in New York City." Social Science \& Medicine 159:1-13. doi: 10.1016/j.socscimed.2016.04.024

Stellar, J. E., John-Henderson, N., Anderson, C. L., Gordon, A. M., McNeil, G. D., \& Keltner, D. (2015, April.) Positive affect and markers of inflammation: discrete positive emotions predict lower levels of inflammatory cytokines. Emotion (Washington, D. C.), 15(2), 129-33. https://doi.org/10.1037/ emo0000033

Thoits, P. A. (2005). The sociology of emotions. Annual Review of Sociology, 15, 317-42.

Tugade, M. M., Fredrickson, B. L., \& Barrett, L. F. (2004). Psychological resilience and positive emotional granularity: Examining the benefits of positive emotions on coping and health. Journal of Personality, 72(6), 1161-1190. https://doi.org/10.1111/j.1467-6494.2004.00294.x

Turner, J. H., \& Stets, J. E. (2005). The sociology of emotions. Cambridge University Press, 2005.

Uskul, A. K., \& A. B. Horn, A. B. (2006, June 1). Emotions and health. In Wright, J. D., (Ed.). International Encyclopaedia of Social and Behavioral Sciences. Elsevier. https://kar.kent.ac.uk/44743/ 